\title{
IAMJ
}

INTERNATIONAL

AYURVEDIC

MEDICAL JOURNAL

do) 2 (

Case Report

ISSN: 2320-5091

Impact Factor: 6.719

\section{MANAGEMENT THROUGH AYURVEDIC MEDICATIONS AND LIFESTYLE MODIFICATION (PATHYASEVANA AND YOGASANA) IN A CASE OF POST-COVID COMPLICATION DIABETES MELLITUS (TYPE 2 DM): A SINGLE CASE STUDY}

\author{
Prajakta D. Nimje ${ }^{1}$, Vidya Wasnik (Thatere) ${ }^{2}$, Sumeeta Jain ${ }^{3}$ \\ ${ }^{1} \mathrm{PG}$ Scholar, ${ }^{2}$ Associate Professor, ${ }^{3} \mathrm{HOD}$ \\ Swasthavritta and Yog Department, Government Ayurved College, Nagpur, Maharashtra, India
}

Corresponding Author: pnimje3003@gmail.com

https://doi.org/10.46607/iamj5409102021

(Published Online: October 2021)

Open Access

(C) International Ayurvedic Medical Journal, India 2021

Article Received: 20/09//2021 - Peer Reviewed: 05/10/2021 - Accepted for Publication: 06/10/2021

\section{Check for updates}

\begin{abstract}
Diabetes is an asymptomatic disease in most people, so there could be a good number of people who may not be aware of their diabetes before they caught COVID-19. Some studies state that in poorly resourced countries, as many as $50 \%$ of people with chronic illnesses, such as diabetes, are undiagnosed. Theoretically, COVID-19 can also cause diabetes as the pancreas have ACE2 receptors, which can enable SARS COV2 to enter the pancreatic beta cells, resulting in structural and functional damage. The present study is carried out to know the traditional Ayurvedic treatment for Diabetes Mellitus. For Diabetes Ayurvedic drugs, Pathyasevana and Yogic lifestyle are one of the best choices of management for their prime role in maintaining blood sugar levels and preventing Diabetes. The present study showed a significant effect on associated complaints. Objectives: - To study the effect of Ayurvedic medications and lifestyles modification (Pathyasevana and Yogasana) on Post Covid complications Type 2 Diabetes Mellitus. Materials and Methods: A 33-year-old male, reported to the Government Ayurveda college and hospital, Nagpur. With complaints of loss of appetite, weakness, sweet taste of mouth, mild polydipsia, mild polyurea excessive mental stress, and Insomnia for the last two months. For that, he had taken treatment of allopathic medicine for a few days, but he was not satisfied. He had been given Ayurvedic medications for 3 months. Appropriate modifications were done at diet and lifestyle as per Ayurvedic text. Proper Yoga protocol was provided to him. Fasting and Post Prandial blood sugar levels were measured by an electronic glucometer before and after treatment. Result: - Improvement in subjective and objective symptoms was found. .
\end{abstract}


Mild to moderate improvement was noted in weakness, sweet taste of mouth, mild polydipsia, mild polyurea, Insomnia was reduced. Conclusion: - Ayurvedic medicines and lifestyle modifications can be considered as a mainstream treatment in the case of newly diagnosed post covid diabetes mellitus.

Keywords: Diabetes Mellitus, Post covid complication, Yogasana, Lifestyle modification.

\section{INTRODUCTION}

Diabetes is an asymptomatic disease in most people, so there could be a good number of people who may not be aware of their diabetes before they caught COVID-19. There are studies that state that in poorly resourced countries, as many as $50 \%$ of people with chronic illnesses, such as diabetes, are undiagnosed. Several patients, even when they know that they have diabetes, are either unable to afford medical care or are not managing the disease well, resulting in only about 1 in 8 patients with diabetes have their blood sugar level optimally controlled. Then there are people who may have had the tendency to develop diabetes, and COVID-19 has caused what we called stress hyperglycemia. In some patients, it could be a combination of stress hyperglycaemia and medications such as steroids that can lead to an increase in blood sugar levels. And finally, there is an ongoing discussion about the possibility of COVID19 disease itself causing new-onset diabetes in a patient.

Coronavirus can cause inflammation, hormonal infection or febrile illness can elevate blood sugar levels. It is a consequence of the mechanism that the body employs to fight the infection. In some cases, the medicines given to treat that infection may cause this rise in blood sugar levels. When there is an increase in inflammatory markers, an extreme example of which is the "cytokine storm" in the case of COVID-19, it affects both the insulin release by the pancreas as well as the sensitivity of the tissue to insulin. Insulin facilitates the movement of glucose into tissues and any malfunctioning (either in production or tissue sensitivity) will lead to elevation of glucose levels in the blood. In the case of COVID19, a patient with moderate to severe disease may need to be given steroids, which can also lead to an increase in the blood sugar levels of patients. in the body, blood clots and other serious health conditions. Some asymptomatic, mild, moderate or severely affected patients have elevated levels of blood sugar. It's possible these patients have pre-diabetes (when your blood sugar levels are higher but can't be classified as diabetes) or pre-existing conditions before SARS-CoV-2 infection, due to steroid and insulin-dependent treatment diabetes triggered. In these patients, COVID-19 can affect blood sugar levels that cause diabetes after covid recovery may remain for their lifetime. It has been observed 25 to $30 \%$ patients those treated in hospital due to severe symptoms developed diabetes or high blood sugar level after COVID-19 recovery. As per recent studies, coronavirus spike protein can cause damage to pancreas Beta cells that is responsible to secrete insulin, due to cells damage pancreas is not able to maintain normal blood sugar levels and regulate glucose into the body's cells.

All eight studies were retrospective cohort studies, consisting of four from China ${ }^{[1,2]}$ two from Italy ${ }^{[3}$ ${ }^{4]}$ and two from the United States. ${ }^{[5,6]}$ All studies were conducted during the first 5 months of the pandemic (i.e. January-May 2020). The mean or median age of patients in these studies varied from 47 to 65.5 years. All the studies (except for two with no data on sex) ${ }^{[7,8]}$ had more males than females, with the proportion of males ranging from $52.1 \%$ to $67.1 \%$. Data on new-onset diabetes were available in two studies and three studies (or cohorts) had previously undiagnosed diabetes cases. In six studies (or cohorts), ${ }^{[9,10]} \mathrm{HbA} 1 \mathrm{c}$ was not performed for all participants, so it was not possible to differentiate between new-onset and previously undiagnosed diabetes. In the majority of studies $(n=6),{ }^{[11]}$ the exact time of detection of newly diagnosed diabetes was not reported, whereas, in two studies, ${ }^{[12]}$ the 
diagnosis was made within 24 hours to 3 days after hospital admission. Only one study reported on the type of diabetes (i.e. type 2 diabetes). ${ }^{[13]}$ The quality of studies was either fair or good, with most $(n=6$; $75 \%$ ) studies being of good quality. With a total of 3711 COVID-19 patients with 492 cases of newly diagnosed diabetes from eight studies, the random effects meta-analysis estimated a pooled proportion of $14.4 \%$ (95\% CI: $5.9 \%-25.8 \%$ ) with a high degree of heterogeneity. Since the prevalence of diabetes is being common during Covid 19. Hence, this study is planned to foresee the management through Ayurvedic Medications and Lifestyle modification (Pathyasevana and Yogasana) in a case of Post Covid complication Diabetes Mellitus (Type 2 DM).

\section{A CASE REPORT}

A 33-year-old male, reported to the Government Ayurveda College and hospital, Nagpur. With complaints of loss of appetite, weakness, sweet tastes of mouth, mild polydipsia, mild polyurea excessive mental stress, and Insomnia for the last two months. For that, he had taken treatment of allopathic medicine for a few days, but he was not satisfied. When he visited OPD first of all we carried out his routine blood investigation as complete blood count, Blood Sugar level, renal function test, Urine routine examination and thyroid function to rule out any possible associated disorders. All the investigations were found within the normal limit, but the Blood glucose level was raised than the normal value. $\mathrm{He}$ has known a case of hypertension for 3 years. There was no significant past history of any other chronic illness inpatient. No history of any type of addiction was found. $\mathrm{He}$ was given some Ayurvedic medications, a chart of pathyaapathya diet and a Yogic lifestyle.

\section{General Examination}

\begin{tabular}{|l|l|}
\hline Pulse rate & $76 / \mathrm{min}$ \\
\hline Respiration rate & $26 / \mathrm{min}$ \\
\hline Temperature (0F) & $97.60 \mathrm{~F}$ \\
\hline Blood pressure & $130 / 70 \mathrm{mmHg}$ \\
\hline Body Weight & $57 \mathrm{~kg}$ \\
\hline Height & 5.5 \\
\hline
\end{tabular}

\section{Systematic Examination}

Respiratory system - Chest bilateral clear, no abnormality detected

Cardiovascular System: S1S2normal

Gastrointestinal System: no abnormality was detected
Locomotors System: normal

Nervous System: The patient was conscious, well-oriented, no abnormality detected

K/c/o -HTN since 3 years

Family history - No

Ashtavidh Parikshan

\begin{tabular}{|l|l|}
\hline Nadi (Pulse) & $76 /$ min \\
\hline Mutra (Urine) & Normal \\
\hline Mala (Stool) & Regular \\
\hline $\begin{array}{l}\text { Jivha } \text { (Tongue) } \\
\text { Shabd } \text { (Speech) }\end{array}$ & Clear \\
\hline Sparsh (Touching) & Anushnashit \\
\hline Druk (Vision) & Prakrut \\
\hline Akruti (Stature) & Madhyam \\
\hline
\end{tabular}


Blood Investigations

\begin{tabular}{|l|l|l|l|l|l|l|}
\hline Sr. No. & Date & Blood Sugar Level & HbA1C & Mean Blood Glucose & KFT - Blood urea & LFT - Globulin \\
\hline 1 & $23 / 04 / 2021$ & $\begin{array}{l}\text { Fasting 140mg/dl } \\
\text { Postprandial 250mg/dl }\end{array}$ & $13.8 \%$ & $349.36 \mathrm{mg} / \mathrm{dl}$ & $55.6 \mathrm{mg} / \mathrm{dl}$ & $2.40 \mathrm{~g} / \mathrm{dl}$ \\
\hline 2 & $24 / 04 / 2021$ & $\begin{array}{l}\text { Fasting 160mg/dl } \\
\text { Postprandial 240mg/dl }\end{array}$ & & & \\
\hline 3 & $24 / 04 / 2021$ & $\begin{array}{l}\text { Fasting 110mg/dl } \\
\text { Postprandial 260mg/dl }\end{array}$ & & & \\
\hline 4 & $30 / 04 / 2021$ & $\begin{array}{l}\text { Fasting 110mg/dl } \\
\text { Postprandial 220md/dl }\end{array}$ & & & \\
\hline
\end{tabular}

Chief Complaints: Loss of Appetite, Weakness, Sweet Taste of Mouth, Mild Polydipsia, Mild Polyurea, Excessive Mental Stress, Insomnia

\section{Personal History}

Wake up at 5.40 am, Bowel habit - Regular, Water intake at morning - 2 glasses of warm water, Morning walk - Daily 3-kilometre, Exercise
(Yogasana and Pranayam) - Pavanmuktasana, Gomukhasana, Tadasana - 10 min, Anuloma-Vilom, Kapalbhati - $10 \mathrm{~min}$, Breakfast at 8 am, Lunch at 1.00 pm, Daytime sleep - No, Tea - 3- 4 pm (2 times a day), Dinner at $9.00 \mathrm{pm}$

Addiction - No

\section{Dietary Habits}

\begin{tabular}{|c|c|c|}
\hline & Time & Habits \\
\hline Breakfast & $\begin{array}{l}8.30 \quad- \\
9.00 \mathrm{am}\end{array}$ & $\begin{array}{l}\text { Upma/Poha/ } 2 \text { Chapati, } 1 \text { bowl vegetable/ Multigrain chapati/Fruits/ sometimes } \\
\text { fermented food like Idli, Dosa/ Black tea/ Kadha }\end{array}$ \\
\hline Lunch & $\begin{array}{l}1.00-1.30 \\
\mathrm{pm}\end{array}$ & $\begin{array}{l}2 \text { - } 3 \text { Chapati, } 1 \text { bowl vegetable, } 1 \text { bowl rice, lbowl salad (carrot, cucumber, radish, } \\
\text { Tomato, Coriander leaves, green chilli, } 1 / 2 \text { tsp black salt), sometimes } 1 \text { cup curd, } 1 \text { cup } \\
\text { Takra (Buttermilk), coconut - groundnut chutney, Tomato chutney, } 1 \text { RostedPapad, } \\
\text { Mango pickles. }\end{array}$ \\
\hline Snacks & $\begin{array}{l}4.00- \\
5.00 \mathrm{pm}\end{array}$ & 1 cup tea/ Coconut water/Fruits juice/ 1 plate Churmuri Chiwda (Puffed Rice) \\
\hline Dinner & $9.00 \mathrm{pm}$ & $\begin{array}{l}2 \text { Fulke, } 1 \text { bowl Vegetable, } 1 \text { bowl mung usual/mataki usal/ vatana usal,1 bowl toor dal } \\
\text { (Cejanus cajan), } 1 \text { bowl Rice, } 1 \text { Jwari Chapati, Roasted Tomato -Chill - Coriander } \\
\text { chutney, Mung dal halwa/ Suji halwa, } 1 \text { bowl curd with } 1 \text { tsp sugar, } 1 \text { bowl salad } \\
\text { (Carrot, Tomato, Cucumber, Coriander leaves sprinkle with black salt ). }\end{array}$ \\
\hline Sleep & $11.15 \mathrm{pm}$ & Disturbed \\
\hline
\end{tabular}

\section{MATERIALS AND METHODS}

After obtaining written informed consent, he was given a treatment plan, lifestyles modification plan (Pathyasevana) and Yoga protocol for three months. He had taken the medications properly with proper dose and duration. He followed a lifestyle modification plan for three months.

Along with the below medications, the patient was advised to take Amalaki Juice (20ml) with
Haridrachurna (1g), Fenugreek bheej with lukewarm water in the morning, daily outdoor walk for 11 hours, Avoidance of Diwaswapan i.e. sleeping during the day.

\section{Treatment Planned}

The following oral medicines were administrated for three Months: 


\begin{tabular}{|c|c|c|}
\hline Date & Medications & Duration \\
\hline \multirow[t]{3}{*}{$1 / 05 / 2021$} & $\begin{array}{l}\text { 1) Mahalakshmi Vilas Rasa 100mg } \\
\text { Nishaamalaki Churna } 125 \mathrm{mg} \\
\text { Giloysatva } 500 \mathrm{mg}\end{array}$ & BD with honey before meal \\
\hline & 2) Chandraprabhavati 2 tab & BD with lukewarm water after meal \\
\hline & 3) Sutshekar Ras 2Tab & BD with lukewarm water before a meal \\
\hline $1 / 06 / 2021$ & $\begin{array}{l}\text { 1) Mahalakshmi Vilas Rasa 100mg } \\
\text { Nishaamalaki Churna } 125 \mathrm{mg} \\
\text { Giloysatva } 500 \mathrm{mg} \\
\text { 2) Chandraprabhavati } 2 \mathrm{tab} \\
\text { 3) Sutshekar Ras } 2 \mathrm{Tab} \\
\text { 4) Jamunbeejchurna - } 30 \mathrm{gm} \\
\text { Vijaysarchurna - } 30 \mathrm{gm} \\
\text { Gudmar churna - } 30 \mathrm{gm}\end{array}$ & $\begin{array}{l}\text { BD with honey before meal } \\
\text { BD with lukewarm water after meal } \\
\text { BD with lukewarm water before a meal } \\
1 \text { tsp OD before a meal with lukewarm water }\end{array}$ \\
\hline $1 / 07 / 2021$ & $\begin{array}{l}\text { 1) Jamunbeejchurna - } 30 \mathrm{gm} \\
\text { Vijaysarchurna - } 30 \mathrm{gm} \\
\text { Gudmar churna - } 30 \mathrm{gm}\end{array}$ & 1 tsp OD before a meal with lukewarm water \\
\hline
\end{tabular}

Dietary Advice for three months

\begin{tabular}{|c|c|c|c|}
\hline $\begin{array}{l}\text { Sr. } \\
\text { No. }\end{array}$ & & Time & Food \\
\hline 1 & Breakfast & $\begin{array}{l}8.00- \\
9.00 \\
\text { am }\end{array}$ & $\begin{array}{l}1 \text { plate Upma/ Sprout ( } 1 \text { bowl Mung Usal/ Mataki Usal/ Chana Usal) / Lahi/Soji/ Broken } \\
\text { wheat porridge/ veg oatmeal/ } 3 \text { chapati with } 1 \text { bowl veg or dal/ Mung kadhan (Soup)/ khakra/ } \\
\text { MultigraineParatha/ Multigrainetoast/ egg white/ Fruits/ } 2 \text { bowl Salad (Carrot, Cucumber, } \\
\text { Tomato, Coriander leaves, black salt)/ Juices (Amla/ Jamun/ Alovera/ Karela (Bitter gourd)/ } \\
\text { Gauva)/ Coconut water/ } 1 \text { tsp fenugreek powder or seed - Amla powder with } 1 \text { glass of } \\
\text { lukewarm water/Vegetables soup. }\end{array}$ \\
\hline 2 & Lunch & $\begin{array}{l}10.00- \\
12.00 \\
\text { am }\end{array}$ & $\begin{array}{l}\text { 2-3 Fulke/ } 1 \text { bowl rice/1 bowl Mung, kulattha dal/ Ladyfinger (Bhindi), Cauliflower, Cabbage, } \\
\text { Beans, Spinach, Mushroom, Eggplant, Capsicum, Bottle gourd, Ridge gourd, round gourd, } \\
\text { Radish, Pumpkin, Peas, Green beans, Fenugreek leaves, Broccoli, Cucumber, Beetroot, } \\
\text { Ginger, Green chilli, green pepper, Coriander, Turnip, Mint, Curry leaf, drink } 1 \text { cup } \\
\text { buttermilk, } 1 \text { bowl Salad (Cucumber, Carrot, Raddish, Tomato, Coriander leaves) }\end{array}$ \\
\hline 3 & $\begin{array}{l}\text { Evening } \\
\text { snacks }\end{array}$ & $\begin{array}{l}5.00 \\
\mathrm{pm}\end{array}$ & $\begin{array}{l}1 \text { bowl Puffed rice (Kurmura), Air-popped popcorn, Roasted Chickpeas, Fruits } \\
\text { (Jamun/Guava/Apple) }\end{array}$ \\
\hline 4 & Dinner & $\begin{array}{l}7.00 \\
\mathrm{pm}\end{array}$ & Sorghum (Jwari)/ Barley/ Ragibhakri, Mung dal khichadi, 1 bowl vegetable, Salad \\
\hline 5 & Water & & $\begin{array}{l}\text { Warm water } \\
\text { Mustasidhhajalsevan }\end{array}$ \\
\hline 6 & Sleep & $\begin{array}{l}10.30 \\
\mathrm{pm}\end{array}$ & \\
\hline 7 & Avoids & & $\begin{array}{l}\text { Daytime sleep } \\
\text { Sweet, dairy products like curd, paneer, cheese etc. } \\
\text { Refrigerated, salty, spicy and deep oil fried food. }\end{array}$ \\
\hline
\end{tabular}




\section{Yoga Protocol for three months}

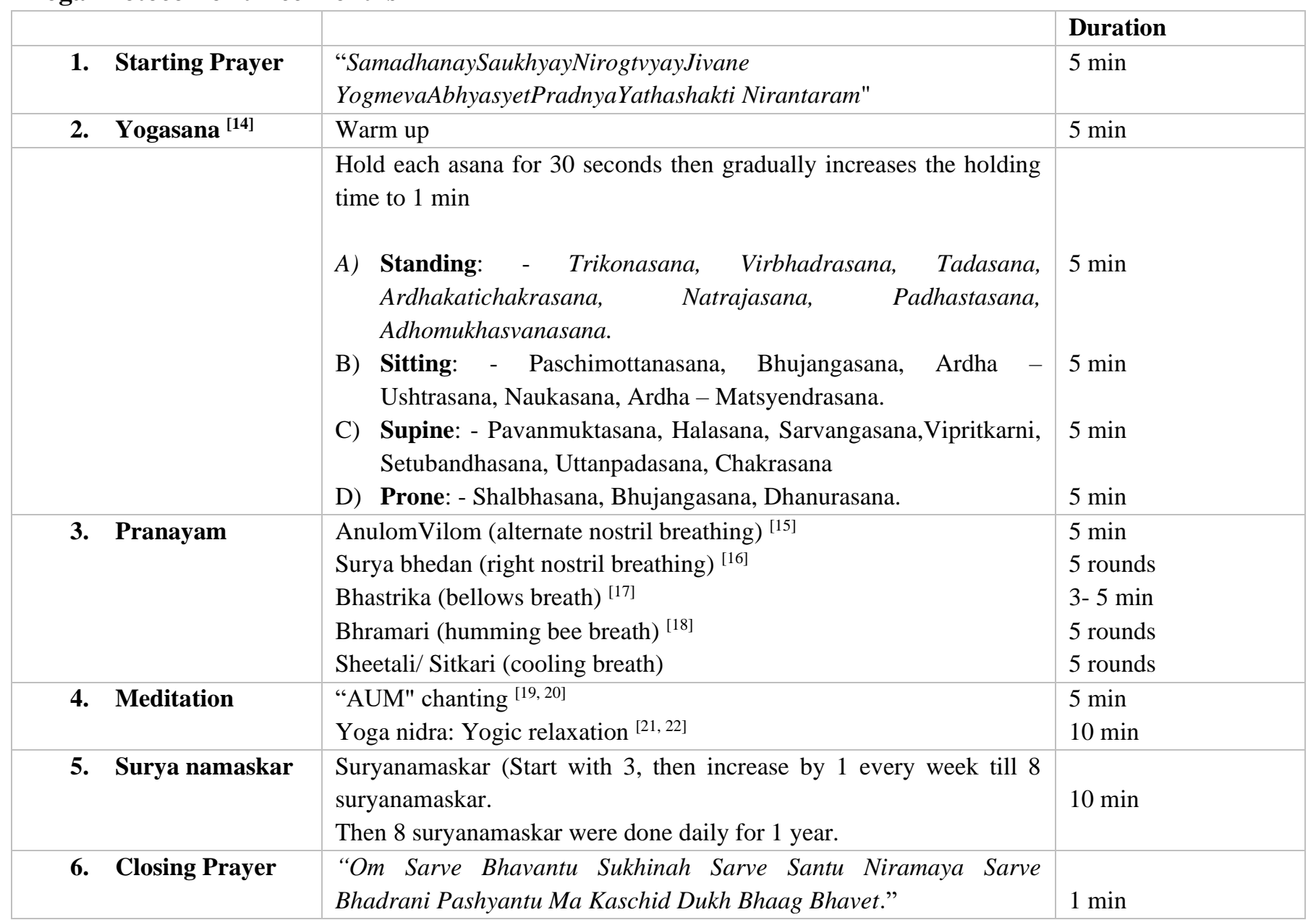

The assessment was done using a calibrated electronic glucometer - the same batch of strips, as well as the same electronic batch chip, was used for checking fasting and post-prandial blood sugar levels before and after the treatment.

\section{Results}

On the first follow up (after 25 days of the treatment) patient reported a reduction in previously mentioned symptoms. Mild to moderate improvement was noted in weakness, sweet taste of mouth, mild polydipsia, mild polyurea, Insomnia was reduced. On the second follow up (35th day) patient felt a lightness and energy in routine activity, mental stress was also reduced.

Improvement in subjective and objective symptoms was found is mentioned in the table.

\begin{tabular}{|c|c|c|c|c|}
\hline Assessment Criteria & Date & Before Treatment & Date & After Treatment \\
\hline Objective & $23 / 04 / 2021$ & $\begin{array}{l}\text { Fasting } 140 \mathrm{mg} / \mathrm{dl} \\
\text { Post Prandial } 250 \mathrm{mg} / \mathrm{dl}\end{array}$ & $18 / 05 / 2021$ & $\begin{array}{l}\text { Fasting } 79 \mathrm{mg} / \mathrm{dl} \\
\text { Post-Prandial } 227 \mathrm{mg} / \mathrm{dl}\end{array}$ \\
\hline & $24 / 04 / 2021$ & $\begin{array}{l}\text { Fasting } 160 \mathrm{mg} / \mathrm{dl} \\
\text { Post Prandial } 240 \mathrm{mg} / \mathrm{dl}\end{array}$ & $02 / 06 / 2021$ & $\begin{array}{l}\text { Fasting } 79 \mathrm{mg} / \mathrm{dl} \\
\text { Post Prandial } 165 \mathrm{mg} / \mathrm{dl}\end{array}$ \\
\hline & $24 / 04 / 2021$ & $\begin{array}{l}\text { Fasting } 110 \mathrm{mg} / \mathrm{dl} \\
\text { Post Prandial } 260 \mathrm{mg} / \mathrm{dl}\end{array}$ & $18 / 06 / 2021$ & $\begin{array}{l}\text { Fasting } 85 \mathrm{mg} / \mathrm{dl} \\
\text { Post Prandial } 163 \mathrm{mg} / \mathrm{dl}\end{array}$ \\
\hline & $30 / 04 / 2021$ & Fasting $110 \mathrm{mg} / \mathrm{dl}$ & $30 / 04 / 2021$ & Fasting $79 \mathrm{mg} / \mathrm{dl}$ \\
\hline
\end{tabular}




\begin{tabular}{|l|l|l|l|}
\hline \multirow{3}{*}{ Subjective } & Post Prandial 220md/dl & Post Prandial $156 \mathrm{mg} / \mathrm{dl}$ \\
& Loss Of Appetite +++ & Loss Of Appetite + \\
& Weakness +++ & Weakness + \\
& Sweet Taste Of Mouth ++ & Sweet Taste Of Mouth + \\
& Mild Polydipsia ++ & Mild Polydipsia + \\
& Mild Polyurea ++ & Mild Polyurea + \\
& Excessive Mental Stress +++ & Excessive Mental Stress + \\
& Insomnia ++++ & Insomnia + \\
\hline
\end{tabular}

\section{DISCUSSION}

Now a day, post covid complications are common due to overdoses of modern medicines. Hence a comprehensive treatment of Ayurvedic medications was given to the patient. Also, exercises and diet which would reduce the vitiation of Kapha Dhatu were given Mahalakshmi Vilas Rasa, Chandraprabha and Nishaamalaki have been mentioned in Ayurvedic scriptures in Prameha Adhikar. Hence, they were chosen for study. All these medicines are known to act on vitiated Kapha Dhatu and Aamsanchaya in the body. Chandraprabha is a potent Mehantak and also helps maintain the urinary system by eliminating kleda in the body. In Chandraprabha Vati as well most of the ingredients exhibited glucose-lowering activities. Chandraprabhavati formulation is mostly effective in Kapha and Vata-Dosha. The majority of drugs have Katu, Tikta, Kashaya Rasa and the prime Virya is Ushna, dominant Vipaka is Katu-Vipaka which helps in reducing the symptoms of Prameha. [23] Nishaamalaki have also been mentioned in Charak Samhita Pramehaadhikar. It is known to reduce the kledasanchaya in the body. Navaprameha is said to be sadhya. It has antidiabetic and antihyperglycaemic properties. In Nishaamalaki Churna maximum drugs possess Kashaya, Tikata rasa, Laghu, Ruksh guna. Prameha is caused by Kapha, Vata, Pitta, Medo Dushti, as Nishaamalaki Churna had Vata-Kaphahara properties due to Sheeta, Ushna Veerya and Madhura, Katu Vipaka. This Rasa and Vipaka of the drugs help in alleviating the Prameha. [23] Jamun Churna has anti-diabetic properties. Jamboline and jambosine in jamun seeds are potent and have medicinal properties that can facilitate quicker healing. These phytochemicals help in slowing down the release of sugar and giving a boost to insulin production - the two functions that are important for keeping diabetes under control. It contains alkaloids, which convert starch into energy and help in reducing diabetes symptoms like constantly feeling thirsty and frequent urination. Jamun seeds, in powdered form, can help in reducing blood sugar levels. They are rich in fibre which can give a boost to the digestive system. A healthy digestive system can help in giving a boost to immunity and reduce risks and side effects associated with diabetes. ${ }^{[24]}$ Vijaysar increases digestive power and increase insulin production in the body. ${ }^{[25]}$ According to Ayurveda, Vijayasar is good for managing high sugar levels by improving metabolism due to its Tikta (bitter) and Kapha-Pitta balancing properties. Vijayasar also helps manage diabetic related symptoms like frequent urination, excessive thirst, fatigue and overeating due to its Kashaya (astringent) property. Due to its Tikta (bitter) nature, it helps manage blood sugar levels by preventing damage to pancreatic cells and promoting insulin secretion due to its antioxidant and anti-inflammatory activity. [26] Gudmar (Gurmar) is effective in managing diabetes (type 2) due to its antioxidant and anti-inflammatory properties. It prevents the pancreatic cells from damage caused by free radicals and increases insulin secretion thereby lowering the blood sugar level. ${ }^{[27]}$ Mustasiddha jala is a powerful digestive that readily triggers the secretion of gastric juices thereby improving appetite, promoting digestion and enhancing liver functions. Touted as "AmaPachak" in Ayurveda, Musta removes toxins or Amadoshas from the body and prevents the conversion of Ama into Amavisha. Additionally, it is also used for the management and treatment of indigestion, loss of appetite, constipation. Due to 
intrinsic hypoglycaemic property, Nagarmotha plays a key role in pacifying the blood sugar levels in the body. The production of insulin from the $\beta$-pancreatic cells becomes active. It helps to attenuate the breakdown of starch into glucose which in turn leads to low blood glucose levels and thus helps in managing diabetes. ${ }^{[28]}$ Fenugreek seeds (trigonella foenumgraecum) are high in soluble fibre, which helps lower blood sugar by slowing down digestion and absorption of carbohydrates. ${ }^{[29]}$ Amlaki Swaras is a good source of vitamin C. It is a powerful antioxidant that will help reverse the free radical generation and the effect of oxidative stress. The consumption of Amla products regularly can prevent the chances of diabetes. In another mechanism, Amla's fibres can help absorb the excess sugar in the body to regular blood sugar levels. ${ }^{[30]}$ Asana is considered to be the third Anga of Ashtanga Yog. As compared to other faculties of yoga, Asanas have gained much popularity in this modern era. Acharya Patanjali has defined Asana as 'Sthir sukham asanam' ${ }^{[31]}$ which not only strengthen the body physically but also relaxes body and mind. Asanas produce beneficial effects in diabetes by affecting insulin kinetics. They help the release of stored insulin from the pancreas and increase the utilisation and metabolism of glucose in the peripheral tissues and liver ${ }^{[32]}$. Asanas improve blood supply to muscles thus enhancing insulin receptor expression in the muscles, causing increased glucose uptake [33]. Pranayama practices itself to destroy obesity and other disorders. Pranayama augments cerebral blood flow and oxygenation that improves neuronal activities of brain centres including those present in limbic areas, and medulla and improves sympathovagal flow ${ }^{[34]}$.

1. Anulom Vilom (Alternate nostril breathing): Regular practice of Nadishuddhi leads to leanness of body, increases glow and ignites the digestive fire. Anulom Vilom is found useful in diabetes as it has calming effects on the nervous system, facilitating homeostasis thus managing the stress levels ${ }^{[35]}$.
2. Suryabhedi (Right nostril breathing): It destroys Vata related disorders and ignites digestive power. Stimulation of the sympathetic nervous system and Pingala nadi removes dullness from body and mind and the heat produced through the practice burns up the impurities in the body. It increases metabolism and oxygenation by increasing the output of adrenaline from the adrenal medulla ${ }^{[36]}$.

3. Ujjayi: It alleviates the Kanthagat Kapha dosha and is Agnivardhak. It also destroys all the Dhatugat doshas. It tackles autonomic nervous centres and sub-cortical centres by reducing.

4. 'Arousal' of RAS (Reticular activating system) and establishes more parasympathetic tone in the body. Other autonomic functions such as blood pressure, gastrointestinal activity and endocrinal secretions are also properly regulated.

5. Bhramari: it influences multiple systems in the body and has desirable effects on the respiratory system, autonomic nervous system, anxiety level and overall emotional status of the practitioner [35]. Bhramari helps to awaken the psychic sensitivity and awareness of subtle vibrations. The sound produced in bhramari is very soothing and relieves mental tension and anxiety.

6. Bhastrika: It is Tridoshnashak and increases the digestive fire. It reduces the BMI and waist-hip ratio in obese patients thus has a significant role in weight reduction. ${ }^{[36]}$ The rapid and rhythmic pumping of the diaphragm and lungs stimulates the heart and blood circulation to the visceral organs, and this creates the massaging effect throughout the whole system.

In a recent study, it was seen that there was a statistically significant decline in fasting and postprandial blood sugar levels in the patients practising meditation as compared to those not practising meditation ${ }^{[37]}$. Ayurveda provides various methods for the better management of the disease in the form of Pathya - Apathya (dietary management). Unfavourable dietary habits and lifestyle modifications, associated with urbanization are the most important factors for the development of the 
disease. According to Ayurveda, it is included in Yapya disease (difficult to cure). So, in order to prevent the onset of this disease, lifestyle modifications, as well as Yogasanas, plays an important role as it ensures good glycemic control and also helps in increasing the quality of life. ${ }^{[38]}$ Hence efforts are also being made to duly reduce the Ayurvedic medicines of the patient and ask him to follow only the lifestyle modifications.

\section{CONCLUSIONS}

There is a significant effect of Ayurvedic medicines and lifestyle modification in the management of post covid complications diabetes mellitus. Hence Ayurvedic medicines and lifestyle modifications can be considered as a mainstream treatment in case of newly diagnosed post covid diabetes mellitus.

\section{REFERENCES}

1. Wang S, Ma P, Zhang S, et al. Fasting blood glucose at admission is an independent predictor for 28-day mortality in patients with COVID-19 without a previous diagnosis of diabetes: a multicentre retrospective study. Diabetologia, 2020; 63(10): 21022111.

2. Zhou W, Ye S, Wang W, LI 5, Hu Q. Clinical features of COVID-19 patients with diabetes and secondary hyperglycemia. / Diabetes Res. 2020; 2020: 1-9.

3. Fadini GP, Morieri ML Boscari F, et al. Newly diagnosed diabetes and admission hyperglycemia predicts COVID-19 severity by aggravating respiratory deterioration. Diabetes Res ClinPract, 2020; 168:108374P.

4. Lampasona V. Secchi M. Scavini M, et al. Antibody response multiple antigens of SARS-CoV2 in patients with diabetes: an observational cohort study. Diabetologia, 2020; 63(12): 2548-2558)

5. Seiglie J, Platt J, Cromer 53, et al. Diabetes as a risk factor for poor early outcomes. hospitalized with COVID-19. Diabetes Care. 2020; 43: 2938-2944,

6. Smith SM, Boppana A. Traupman JA, et al. Impaired glucose metabolism in patients with diabetes, prediabetes, and obesity is associated with severe COVID-19. J Med Virol. 2020.

7. Wang S, Ma P, Zhang S, et al. Fasting blood glucose at admission is an independent predictor for 28-day mortality in patients with COVID-19 without a previous diagnosis of diabetes: a multicentre retrospective study. Diabetologia. 2020; 63(10): 21022111.

8. Fadini GP, Morieri ML Boscari F, et al. Newly diagnosed diabetes and admission hyperglycemia predict COVID-19 severity by aggravating respiratory deterioration. Diabetes Res ClinPract, 2020; 168:108374P.

9. Wang S, Ma P, Zhang S, et al. Fasting blood glucose at admission is an independent predictor for 28-day mortality in patients with COVID-19 without a previous diagnosis of diabetes: a multicentre retrospective study. Diabetologia. 2020; 63(10): 21022111.

10. Zhou W, Ye S, Wang W, LI 5, Hu Q. Clinical features of COVID-19 patients with diabetes and secondary hyperglycemia. / Diabetes Res. 2020; 2020: 1-9.

11. Wang S, Ma P, Zhang S, et al. Fasting blood glucose at admission is an independent predictor for 28-day mortality in patients with COVID-19 without a previous diagnosis of diabetes: a multicentre retrospective study. Diabetologia. 2020; 63(10): 22102-2111

12. Seiglie J, Platt J, Cromer 53, et al. Diabetes as a risk factor for poor early outcomes. Hospitalized with COVID-19. Diabetes Care. 2020; 43: 2938-2944,

13. Pal GK. Effects of Pranayama on cardiovascular health. Int J Clin Exp Physiol. 2016; 3:57-58.

14. Aruna Rathod Panvel. Yoga for diabetes. Mumbai Mirror| Updated: Oct 24, 2014. [Available from http://mumbaimirror.indiatimes.com -...- Health and lifestyle-Yoga for diabetes.

15. Kuppusamy $\mathrm{M}$ et al. Effects of Bhramari Pranayama on health. A systematic review. Journal of Traditional and Complementary Medicine. 2018; 8:11-16

16. Telles S, Nagarathna R, Nagendra HR. Breathing through a particular nostril can alter metabolism and autonomic activities. Indian $\mathrm{J}$ Physiol Pharmacol. 1994; 38:133-7

17. Arkiath VR, Deshpande A, Joshi SR. Therapeutic role of yoga in type 2 diabetes. Endocrinol Metab 2018; 33:307-317

18. Sinha SS et al. Effect of 6 months of meditation on blood sugar, glycosylated haemoglobin, and insulin levels in patients of coronary artery disease. Int $\mathbf{J}$ Yoga. 2018;11(2):122-128

19. Arora J, Dubey N. Immediate benefits of "Om" chanting on blood pressure and pulse rate in 
uncomplicated moderate hypertensive subjects. Natl J Physiol Pharm Pharmacol 2018; 8(8):1162-1165.

20. Amita S, Prabhakar S, Manoj I, Harminder S, Pavan T. Effect of yoga-Nidra on blood glucose level in diabetic patients. Indian J Physiol Pharmacol. 2009 Jan-Mar;53(1):97-101. PMID: 19810584.

21. Bharathi R et al. Effect of Kapalbhati Pranayama in the blood sugar level in diabetic patients. Drug Intervention Today. 2018; 11:2235-2237.

22. Choudhary A. Effect of Nishakatakadikwath and Chandraprabhavati inpatient of Prameha(Diabetes Mellitus) - A Case Study. International Journal of Ayu pharma chem 2021, 14(2) p.n. 1- 7

23. https://www.google.com/amp/s/www.ndtv.com/health /jamun-seeds-for-diabetics-know-how-jamun-seedscan-help-with-diabetes-management$2140615 \% 3$ famp $=1$ \&akamai-rum $=$ off

24. https://www.google.com/amp/s/food.ndtv.com/ayurve da/vijaysar-for-diabetes-how-to-use-this-ayurvedicherb-to-manage-blood-sugar-levels$1896685 \% 3$ famp=1\&akamai-rum=off

25. https://www.google.com/amp/s/www.1mg.com/ayurv eda/vijaysar-51/amp

26. https://www.google.com/amp/s/www.1mg.com/ayurv eda/gudmar-86/amp

27. https://m.netmeds.com/healthlibrary/post/nagarmotha-benefits-ingredients-methoddosage-and-side-effects

28. https://www.diabetes.co.uk/naturaltherapies/fenugreek.html

29. https://www.google.com/amp/s/pharmeasy.in/blog/am la-uses-benefits-side-effects/amp/

30. Malhotra V, Singh S, Tandon OP, Sharma SB. The beneficial effect of yoga in diabetes. Nepal Med Coll J. 2005; 7:145-147.

31. Thangasami SR, Chandani AL, Thangasami S. Emphasis of yoga in the management of diabetes. $J$ Diabetes Metab. 2015; 6:613

32. Pal GK. Effects of pranayama on cardiovascular health. Int J Clin Exp Physiol. 2016; 3:57-58.

33. Aruna Rathod Panvel. Yoga for diabetes. Mumbai Mirror| Updated: Oct 24, 2014. [Available from http://mumbaimirror.indiatimes.com -...- Health and lifestyle-Yoga for diabetes.

34. Kuppusamy $\mathrm{M}$ et al. Effects of Bhramari Pranayama on health. A systematic review. Journal of Traditional and Complementary Medicine. 2018; 8:11-16

35. Telles S, Nagarathna R, Nagendra HR. Breathing through a particular nostril can alter metabolism and autonomic activities. Indian J Physiol Pharmacol. 1994; 38:133-7

36. Arkiath VR, Deshpande A, Joshi SR. Therapeutic role of yoga in type 2 diabetes. Endocrinol Metab 2018; 33:307-317

37. Sinha SS et al. Effect of 6 months of meditation on blood sugar, glycosylated haemoglobin, and insulin levels in patients of coronary artery disease. Int $\mathbf{J}$ Yoga. 2018;11(2):122-128

38. Mane Pooja R., Padte Swapnil Role of Pathya Apathya in the management of Apathyanimittaja Prameha w. s. r. to Type - 2 Diabetes Mellitus". Ayurlog: National Journal of Research in Ayurved Science - 2020; 8(4): $1-6$

\section{Source of Support: Nil Conflict of Interest: None Declared}

How to cite this URL: Prajakta D. Nimje et al: Management Through Ayurvedic Medications And Lifestyle Modification (Pathyasevana And Yogasana) In A Case Of Post-Covid Complication Diabetes Mellitus (Type 2 Dm): A Single Case Study. International Ayurvedic Medical Journal \{online\} 2021 \{cited October 2021\} Available from: http://www.iamj.in/posts/images/upload/2619_2628.pdf 